\title{
A IMPORTÂNCIA DO GESTOR ESCOLAR NA CONSTRUÇÃO DO CONHECIMENTO.
}

Semana Online Científica de Educação, 1a edição, de 25/10/2021 a 27/10/2021

ISBN dos Anais: 978-65-81152-18-5

\author{
GOMES; IZANA TEIXEIRA PINHEIRO ${ }^{1}$
}

\section{RESUMO}

O presente trabalho aborda o tema: A importância do Gestor escolar na construção do conhecimento e tem como objetivo geral fazer uma análise acerca da atuação do Gestor escolar, a fim de melhorar a qualidade do trabalho desenvolvido dentro da escola. Além disso, como objetivos específicos desta pesquisa faz-se necessário: Compreender o conceito de Gestão; refletir sobre o papel exercido pelo Gestor escolar; identificar os pontos positivos e negativos dessa função como também apontar as contribuições do Gestor escolar no decorrer do percurso de trabalho. Para atingir tal finalidade optou-se pela abordagem qualitativa, por meio da revisão bibliográfica, como também pela abordagem quantitativa, no intuito de melhorar o desenvolvimento deste trabalho. Utilizou-se um questionário composto de 8 questões, que foram respondidos por professores Pedagogos diretores, e o resultado desta pesquisa confirma que o gestor escolar é de suma importância neste ambiente de trabalho, tendo em vista que o diretor ou gestor escolar exercem um papel de liderança, com planos, estratégias e objetivos a serem alcançados no decorrer do trabalho, que irão somar aos demais setores da instituição escolar para que haja um serviço de qualidade, somando parcerias, trabalho em equipe a ser aplicado juntamente com os demais setores como o Pedagógico, o administrativo, dentre outros e com participação da comunidade escolar, os alunos, pais ou responsáveis, além de adquirir conhecimentos e experiências que ficarão marcadas por toda a vida. Há um imenso caminho a percorrer, obstáculos e possíveis soluções, além de trabalhoso, mas é gratificante. Equipe unida, trabalhos delegados, confiança nas pessoas, escola organizada exercendo seu papel de formar cidadãos, e todos em busca da excelência no trabalho e do conhecimento. Ter um plano com objetivos e metas e conseguir envolver todos os indivíduos no processo, um bom processo de comunicação, gerenciar conflitos, é enfim tarefa de uma boa liderança.

PALAVRAS-CHAVE: Gestão, Qualidade, Experiência, Conhecimento 